\title{
Provincialismos de Costa Rica
}

José Joaquín Borda

Pocas horas hacía que eláncora había caído al fondo del bellísimo golfo de Nicoya, y descansaba yo en medio de la dulce hospitalidad de Puntarenas único puerto de la república de Costa Rica sobre el océano Pacífico. Algunas personas bondadosas, y de quienes conservo los más dulces recuerdos, me habían acompañado de la playa al hotel y comenzaban a suavizarme las horas de una peregrinación que tenía visos de destierro. En las conversaciones que tuve con ellos y con los habitantes de la capital (San José) noté una perfecta identidad en el acento, lo mismo que en las costumbres, con mis paisanos de Cundinamarca y Boyacá. Allí como en estas tierras se acostumbra acentuar los imperativos, usar el vos en lugar de tú uy convertir en diptongos vocales que deben pronunciarse separadas y con distinto acento.

Poné ái los báules, decía un amigo al peón del puerto, mirá que vos sos muy descuidao. Y como me viese bajo un sol de 90 grados, con el grueso vestido de que estaba ataviado para resguardarme de las brisas del mar durante la navegación del Perú a Centro América, volvióse y me dijo:

-Es necesario que usted deje el centro para cuando esté entre los hermaniticos, porque apenas tengan confianza con usted sus nuevos amigos, cuando usted menos lo piense le meterán navaja.

Preciso me fue comprender que al chaleco se daba el nombre de centro y que debía cambiarlo por una camisa de tartán, cuya moda empezaba entonces con furor, como dicen los franceses, moda por cierto muy útil en aquellos países donde se transpira constantemente $\mathrm{y}$ un viento frío puede llevarlo a uno a la tumba. En cuanto a los hermaniticos, supe que así se llamaban mutuamente los costarricenses, y sobre todo los de la capital. 
Preguntéle qué distancia había del puerto a la capital, y me contestó:

-Es largo de aquí. ¡Achará que no hubiera usted llegado tres días antes, porque así le había sido fácil irse en las bestias de mi tata!

Se comprenderá que esa interjección equivale a un iquélástima!, dado a tiempo, y que tata corresponde a padre o mejor dicho, al taita de que hablaban los santafereños.

Aquel excelente sujeto se despidió manifestándome que estaba precisado, y diciéndome que tendría el gusto de enviarme un guacal de ismoyos. Díjele que no conocía tales pájaros, y me replicó:

-No son pájaros sino jocotes.

Tan a oscuras como antes me quedé, pero resolví esperar, temiendo sumergirme en un laberinto más intrincado que el de Creta. Una hora después recibí lo que aquí llamamos una totuma, llena de exquisitas y colosales ciruelas. Y debo confesar que no les hice mala cara, a pesar de que la insigne portadora tenía un güecho o, como decimos por estos mundos, un coto digno del mejor pescuezo de Mariquita.

Al día siguiente debía emprender viaje a San José con un compañero enfermo. Hícele tomar lo que aquí llamamos una clarita; pero no sé si fue de maíz o de arroz, por lo que me es imposible recordar si la cocinera dijo al presentarla:

-Aquí tienen los caballeros el pinol-o si dijo el atol.

Yo por mi parte me contenté con tomar un tibio; es decir, un pocillo de chocolate frío.

En seguida envolví a mi enfermo en un cobo, o frazada negra; eché sobre mi camastro un chamarro, cosa parecida al cobo de mi compañero, y mientras él reposaba de las fatigas del viaje, me recliné en un balcón a contemplar ese divino cielo de estrellas y azul, escuchando el melodioso quejido de las ondas que venían a estrellarse a mis pies convertidas en espumas, entre las cuales chispeaban las partículas fosforescentes, como una polvareda de lentejuelas de oro.

Al día siguiente hubimos de esperar largo tiempo las bestias y consagrar la madrugada a ver la salida del sol, que como una bomba 
de fango nacía de entre las olas, extendiendo sus rayos a manera de un flueco de oro sobre las azules y lindas colinas del murmurante golfo.

La ropa que compré para el viaje a caballo era chinga, es decir, corta; pero en cambio había encontrado un soberbio polvero de la India; quiero decir, un pañuelo de bolsillo. Cambié mi chonete (sombrero viejo) por otro que creía nuevo, pero resultó que era un charro medio compuesto.

Sirviéronme al almuerzo carne de chancho (puerco, con perdón de ustedes) y un nacatamal, o sea un tamal, como se usa en todo país español. Y todo esto junto con un par de camotes, o sea batatas, equivalía por cierto al más espléndido chompipe, es decir al más gordo y suculento pavo, de que pudieran disfrutar dos encamotados, o lo que es lo mismo dos enamorados.

Ya las bestias, por su parte, habían acabado el zacate, que nosotros llamamos pasto; ya nuestra ropa bien envuelta formaba dos estupendos motetes, o si ustedes quieren tarates, y llegó la hora de montar. Las sillas tenían todas pelero o, como decimos, sudadero; pero a la mía le faltaba la tenedora o grupera, en cambio de la cual me dieron un pelloncito de cuero de oveja, diciéndome que aquella zalea me serviría hasta de cama. Los cubos de las sillas estaban relucientes y el pie descansaba cómodamente entre ellos. Por lo demás, cada jinete llevaba al cinto una cuma, hermana gemela de las peinillas de Ocaña, un chilillo para azotar al animal y el suficiente pisto (dinero), entre el cual había algo de bamba (moneda de cordón) y alguna que otra papalota (moneda pelada). Encima de los dos motetes campanilleaban dos totumas y una cazuela, a las cuales el que fungía de arriero les daba el nombre de nambira, jucó y comal. Todo esto iba atado con un mecate, quiero decir con un cordel. Como mi compañero tenía dolor de cabeza, el arriero le dijo:

- No sea usted pelma (cobarde). Usted es demasiado jupón, para que un dolorcito de jupa le impida montar. 
Y cogiendo un tinamaste, quiero decir, una piedra de tres que habían servido para cocinar el almuerzo, lo subió a ella y lo ayudó a colocarse en el caballo.

Empezamos el viaje por las orillas del mar y bajo un sol abrasador; las olas venían murmurando a cobijar la ribera, y empapadas por el dedo de Dios, tornaban a su abismo convertidas en tumbos y gasas de espumas. Las mulas acostumbradas ya a aquel espectáculo imponente, parecían sentir con delicia el agua tibia y salobre que a cada oleada les bañaba los cascos. Después de esto, bosques y llanos no explorados aún por el naturalista, habitados entre otros animales por quezales y jalpas, que nosotros llamamos guacamayas, tapizados de una vegetación poderosa, fresca, verde y salpicada de flores; ríos torrentosos y bellos deslizándose en la profundidad entre altas murallas al parecer a pico.

Cuando entramos a San José después de un viaje que hicimos en siete días, nos acompañaban algunos campiranos o campesinos y dos o tres serranas envueltas en sus rebozos, tan frescas, tan coloraditas y provocativas como la Flérida de Garcilaso.

A pocas vueltas nos vimos emporrados, o si ustedes quieren, molestados por un gentío que se dirigía a la plaza. Había corridas de toros, como en todo país donde se habla la lengua de Castilla y aunque se acercaba el tope o el encierro, algunos hombres se ocupaban todavía en abrir choyas para enclavar las maderas de la barrera. Por supuesto que allí no se veían chonetes sino boleros de luciente felpa negra; había varios corrillos de hablantines, otros de palomillas, o sea artesanos endomingados y algunos jinetes que se preparaban con sendas cuerdas a engazar al toro por los cuernos. Todo esto formaba un molote, como si dijéramos un bochinche. Las ventanas entretanto estaban llenas de niñas y de pelantrines o pisaverdes, como racimos de pejibayes. Eran los que de ordinario la pastoreaban y ahora les decían pericos, que equivale a florear.

No se crea que al insertar estas palabras provinciales lo hacemos por denigrar a Costa Rica. Allí se habla tan bien la lengua castellana 
como en las demás secciones hispanoamericanas, que también tienen sus provincialismos peculiares. Los hemos insertado con el fin de que sean conocidos y más tarde haremos otro tanto con algunos provincialismos de nuestro país. Hemos puesto dos o tres de estas palabras en letra bastardilla, aunque son españolas, por ser totalmente desusadas entre nosotros. 
